Abstracta Iranicacta Iranica

Revue bibliographique pour le domaine irano-aryen

Volume 37-38-39 | 2018

Comptes rendus des publications de 2014-2016

\title{
Abbas Alizadeh. Ancient Settlement Systems and Cultures in the Ram Hormuz Plain, Southwestern Iran
}

Yasmina Wicks

\section{OpenEdition}

1 Journals

\section{Electronic version}

URL: http://journals.openedition.org/abstractairanica/44766

DOI: 10.4000/abstractairanica.44766

ISBN: 1961-960X

ISSN: 1961-960X

Publisher:

CNRS (UMR 7528 Mondes iraniens et indiens), Éditions de l'IFRI

Electronic reference

Yasmina Wicks, « Abbas Alizadeh. Ancient Settlement Systems and Cultures in the Ram Hormuz Plain, Southwestern Iran », Abstracta Iranica [Online], Volume 37-38-39 | 2018, document 1, Online since 30 December 2018, connection on 26 September 2020. URL : http://journals.openedition.org/ abstractairanica/44766 ; DOI : https://doi.org/10.4000/abstractairanica.44766

This text was automatically generated on 26 September 2020.

Tous droits réservés 


\title{
Abbas Alizadeh. Ancient Settlement Systems and Cultures in the Ram Hormuz Plain, Southwestern Iran
}

\author{
Yasmina Wicks
}

\section{REFERENCES}

Abbas Alizadeh, with contributions by Loghman Ahmadzadeh and Mehdi Omidfar, and appendices by John R. Alden, Leah Minc, Jacques Connan, John Zumberge, and Kendra Imbus. Ancient Settlement Systems and Cultures in the Ram Hormuz Plain, Southwestern Iran. Chicago: The University of Chicago, 2014, xl + 324 p., 117 figures, 199 plates, 28 tables, (Oriental Institute Publications 140), ISBN 978-1-885923-97-4.

1 Tall-e Geser boasts a long stratigraphic sequence from the 5th millennium to the Safavid period, broken only during the 700-800 years following the Proto-Elamite period, and it remains the only excavated site in the strategically important Ram Hormuz region connecting the Mesopotamian plain and Susiana with the Zagros highlands. However, the two seasons of excavation at the site led by Donald E. McCown in 1948/49 under the auspices of the Oriental Institute were never published. For this volume, Abbas Alizadeh has gathered together the records of the work at Tall-e Geser preserved in the Oriental Institute archives and used the field notes, observations of McCown's field assistant Joseph Caldwell, and logic of stratification to fill gaps and to correct and finalise "in-progress" section drawings and top plans. Complementing the material from Geser are the results of the author's own intensive surveys of Ram Hormuz undertaken in 2005-2008 to establish long-term population trends and settlement patterns.

During his 1948 season at Tall-e Geser, McCown excavated two trenches in Mound A, which produced no material dating between the mid-second millennium and the 14th-16th centuries AD (his 1949 season was dedicated entirely to this mound). He also 
excavated a trench in Mound B, and a trench in the so-called Fort Mound, both of which contained significant deposits dating from the Sukkalmah to the Achaemenid period. In just four days of work on Mound B, he opened a $13 \times 5$ metre trench to a depth of 5 metres and uncovered three layers dating from the Neo-Elamite (Geser Phase VIII) to the Sukkalmah period. Level 1 was composed of a ca. $2 \mathrm{~m}$ layer of loose dirt and contained pit burials of an adult and two children (G1-G3), which the author assigns to the Neo-Elamite period based on ceramics that are not described or shown. One of the child burials had been cut into a slightly earlier Neo-Elamite wall associated with a fragmentary mud-plastered surface. Neo-Elamite ceramics were also found in the lowest level (three) containing Sukkalmah pottery and architecture, but it is difficult to know what to make of their presence.

3 Excavated over nine days, the $5 \times 28$ metre Fort Mound trench produced a mix of material ranging from the Sukkalmah to Seljuk periods that had been disturbed during construction of the fort. Work was carried out simultaneously in top, centre and base sections, which likely mixed the assemblages even more. The top section produced seven pit burials and one built tomb (G1-G7, B1), the centre section produced four pit burials (G1-G4), and the base section produced one brick-lined burial (B1). Based on McCown's archived field notes, Elizabeth Carter had already published five burials from this mound in 1994, which she assigned to the Neo-Elamite period and labelled as $\mathrm{E}$ and F (top section), K (centre section), and L and M (base section) (Elizabeth Carter "Bridging the Gap between the Elamites and the Persians in Southeastern Khuzistan", in Heleen Sancisi-Weerdenburg, Amélie Kuhrt and Margaret C. Root [eds.] Achaemenid History vol. VIII, 1994, pp. 65-95, Leiden). Surprisingly, Alizadeh makes no mention of Carter's work, and the assessments of the position and context of the materials are in almost all cases irreconcilable between the two authors. To provide three salient examples: 1) a pair of vessels ( $\mathrm{G}-48, \mathrm{G}-100)$ attributed by Carter to burial $\mathrm{K}$ have no recorded context in Alizadeh, and one is dated to the Achaemenid period, the other to the Neo-Elamite period; 2) the vessels that Carter attributes to burial E (G-60, G-65, G-66, G-102) are reported by Alizadeh in different levels without precise context and are dated variously between the Neo-Elamite I and Achaemenid periods; 3) a vessel (G-62) that Carter attributes to burial M in the base level is allocated to Alizadeh's burial G6 in the top level. While Alizadeh cautions that the Fort Mound top plans and section plan are not consistent with each other, introducing difficulties into the interpretation, it is not clear why Carter's work was not accounted for.

4 This publication is clearly essential for our comprehension of the evolution of settlement in an important region of Elam throughout its history. The Neo-Elamite material comprises only a minor portion of the work but is valuable in that it adds a few new burials to our body of evidence and enumerates seven surveyed sites in the Ram Hormuz region with evidence for Neo-Elamite settlement, including Geser, Tappeh Bormi, and the area around the renowned tomb of two elite women at Jobaji (RH-058). Its omission of Carter's previous work, however, introduces some confusion for the reader, as does its exclusion of recent scholarship from its commentary on Neo-Elamite history (for example, no Elamite regents are recognised past the mid-7th century). Likewise, its conclusion that a lack of recognisable Neo-Elamite I ceramics in the region vouches for a widespread Near Eastern "dark age" induced by the "relentless penetration" of Indo-Iranian "hordes" omits discussions of Elamite-Persian 
acculturation, and its assessment that the Elamites had lost much of their power by the mid-6th century is open to debate.

\section{AUTHORS}

\section{YASMINA WICKS}

Department of Archaeology, The University of Sydney 